\title{
Biological control of horse cyathostomin (Nematoda: Cyathostominae) using the nematophagous fungus Duddingtonia flagrans in tropical southeastern Brazil
}

\author{
Fabio Ribeiro Braga ${ }^{\mathrm{a}, 1}$, Jackson Victor Araújo ${ }^{\mathrm{a}, 1, *}$, André Ricardo Silva ${ }^{\mathrm{a}, 1}$, \\ Juliana Milani Araujo ${ }^{\mathrm{a}, 1}$, Rogério Oliva Carvalho ${ }^{\mathrm{a}, 1}$, Alexandre Oliveira Tavela ${ }^{\mathrm{a}, 1}$, \\ Artur Kanadani Campos ${ }^{\mathrm{b}}$, Giovanni Ribeiro Carvalho ${ }^{\mathrm{c}}$ \\ a Departamento de Veterinária, Universidade Federal de Viçosa, Rua PhRolfs s/n, Viçosa-MG, Cep: 36570000, Brazil \\ ${ }^{\mathrm{b}}$ Univiçosa - Faculdade de Ciências Biológicas e da Saúde, Viçosa, MG - 36570000, Brazil \\ ${ }^{\mathrm{c}}$ Departamento de Zootecnia, Universidade Federal de Viçosa, Viçosa-MG, Cep: 36570000, Brazil
}

\section{A R T I C L E I N F O}

\section{Article history:}

Received 18 April 2008

Received in revised form 4 May 2009

Accepted 5 May 2009

\section{Keywords:}

Nematophagous fungus

Duddingtonia flagrans

Cyathostomin

Horse

Biological control

\begin{abstract}
A B S T R A C T
The viability of a fungal formulation using the nematode-trapping fungus Duddingtonia flagrans was assessed for the biological control of horse cyathostomin. Two groups (fungus-treated and control without fungus treatment), consisting of eight crossbred mares (3-18 years of age) were fed on Cynodon sp. pasture naturally infected with equine cyathostome larvae. Each animal of the treated group received oral doses of sodium alginate mycelial pellets $(1 \mathrm{~g} /(10 \mathrm{~kg}$ live weight week $))$, during 6 months. Significant reduction $(p<0.01)$ in the number of eggs per gram of feces and coprocultures was found for animals of the fungus-treated group compared with the control group. There was difference $(p<0.01)$ of $78.5 \%$ reduction in herbage samples collected up to $(0-20 \mathrm{~cm})$ between the fungus-treated group and the control group, during the experimental period (May-October). Difference of $82.5 \%(p<0.01)$ was found between the fungus-treated group and the control group in the sampling distance $(20-40 \mathrm{~cm})$ from fecal pats. During the last 3 months of the experimental period (August, September and October), fungustreated mares had significant weight gain $(p<0.01)$ compared with the control group, an increment of $38 \mathrm{~kg}$. The treatment with sodium alginate pellets containing the nematodetrapping fungus $D$. flagrans reduced cyathostomin in tropical southeastern Brazil and could be an effective tool for biological control of this parasitic nematode in horses.
\end{abstract}

(c) 2009 Elsevier B.V. All rights reserved.

\section{Introduction}

A large variety of helminths are known to parasite horses. Nematodes, mainly cyathostomin species, are the most common and important among them. Also known as small strongyles, cyathostomin infections are responsible for causing anemia, weight loss, intestinal colic, and death

\footnotetext{
* Corresponding author. Fax: +55 3138991464

E-mail address: jvictor@ufv.br (J.V. Araújo).

${ }^{1}$ CNPq scholarship.
}

in horses (Assis and Araújo, 2003). They are the most prevalent parasites in horses, present throughout the year in the pasture, with a wide distribution in different age groups (Barbosa et al., 2001; Quinelato et al., 2008).

Klei and Chapman (1999) reported field data suggesting that horses can acquire resistance to helminths with age, which is confirmed by the reduced parasite load and egg count in feces. This response is slow and inconsistent in most animals and unrelated to the intensity of previous contact with parasite.

Kaplan (2002) and Matthews et al. (2004) discussed that worm control in horses is usually carried out with 
anthelmintic drugs, which have not been totally effective for the control of these nematodes since their action is restricted to adult parasites and there is occurrence of resistance.

The continued use of the same anthelmintic class, as well as the rapid rotation of compound groups, introduction of resistant worms and the use of doses lower than the recommendation should be avoided (Mota et al., 2003). Biological control using natural nematode antagonistic fungi is among the most viable alternatives. These organisms comprise different types of fungi classified into predators, endoparasites and opportunists, whose action is concentrated in the fecal environment and directed against free-living parasitic larvae. Within the predator group, the species Duddingtonia flagrans stands out as the most promising for the control of gastrointestinal nematodiasis in domestic animals (Terrill et al., 2004; Dias et al., 2007a). However, to be used as a biological control agent, nematophagous fungi must have ability for nematode capture and survive passage through gastrointestinal tract (Waller et al., 1994).

Sodium alginate-based formulations containing $D$. flagrans mycelial mass have been experimentally evaluated against parasitic nematodes of animals in laboratory and field conditions (Araújo and Sampaio, 2000; Araújo et al., 2000; Dias et al., 2007b), but none these formulations have been developed for the control of parasitic nematodes of horses in the field.

The objective of the present study was to test an alginate pellet formulation containing $D$. flagrans for the biological control of cyathostomin in horses raised in fields.

\section{Materials and methods}

\subsection{Fungal cultures}

Isolate (AC001) of D. flagrans, a nematode-trapping fungus belonging to the genus Duddingtonia, was kept in test tubes at $4{ }^{\circ} \mathrm{C}$ containing $2 \%$ corn-meal-agar (2\% CMA) in the dark. The isolated was obtained from a Brazilian soil using the soil sprinkling method (Duddington, 1955), modified by Santos et al. (1991).

Fungal mycelia were obtained by transferring culture disks (approximately $5 \mathrm{~mm}$ in diameter) of fungal isolates in $2 \%$ CMA to $250 \mathrm{~mL}$ Erlenmeyer flasks with $150 \mathrm{~mL}$ liquid potato-dextrose medium (Difco), $\mathrm{pH} 6.5$, and incubated under agitation $(120 \mathrm{rpm})$, in the dark at $26{ }^{\circ} \mathrm{C}$, for 10 days. Mycelia were then removed for pelletizing using sodium alginate as described by Walker and Connick (1983) and modified by Lackey et al. (1993).

\subsection{In vivo experimental assay}

The experiment was conducted at the horse experimental sector of the Federal University of Viçosa, Viçosa, MG, Brazil, latitude $20^{\circ} 45^{\prime} 20^{\prime \prime} \mathrm{S}$, longitude $42^{\circ} 52^{\prime} 40^{\prime \prime} \mathrm{W}$, from May to October 2007.

In the beginning of the experiment, the 3-18 year old crossbred mares were previously dewormed with $200 \mu \mathrm{g} /$ $\mathrm{kg}$ live weight Ivermectin $1 \%$ and $6.6 \mathrm{mg} / \mathrm{kg}$ live weight
Pyrantel Pamoate (Centurion Vallé ${ }^{\circledR}$, Montes Claros-Minas Gerais, Brazil).

Fourteen days after the anthelmintic treatment, the mares were separated into two groups (fungus-treated and control) of eight animals each on the basis of age and weight. Mean age and mean weight of the fungus-treated group were $6.3( \pm 6.1)$ and $386.2( \pm 54.07)$ respectively, and $7.1( \pm 4.7)$ and $381.1( \pm 53.91)$ of the control group respectively. Mares were allocated to two 2.5 ha paddocks of Cynodon sp., that had been previously grazed by young and adult horses and were naturally infested with equine cyathostomin larvae. Then, each animal of the treated group received twice a week $1 \mathrm{~g}$ pellets $/ 10 \mathrm{~kg}$ live weight, containing $D$. flagrans mycelial mass combined with $100 \mathrm{~g}$ of horse commercial ration, as described by Assis and Araújo (2003). The treatment was offered during 6 months starting from May 2007. Animals of the control group received $1 \mathrm{~g}$ pellets/ $10 \mathrm{~kg}$ live weight without fungus. From the beginning (May) to the end (October) of the experiment, animals from both groups were monthly weighed. During the experiment, mares were fed daily with $2 \mathrm{~kg}$ of commercial ration with $14 \%$ soybean meal, $83.1 \%$ corn meal, $14.5 \%$ salt, $1.5 \%$ limestone and $14 \%$ protein.

After the mares had been moved to the paddocks, samples of fresh feces were collected once a week directly from the rectum, $72 \mathrm{~h}$ after the treatment, to determine egg per gram of feces (EPG), according to Gordon and Whitlock (1939) and modified by Lima (1989).

Coprocultures were established together with EPG counts; $20 \mathrm{~g}$ of feces were mixed with ground, moistened and autoclaved industrial vermiculite (NS Barbosa Ind Com. ${ }^{\circledR}$ ) and taken to an oven at $26{ }^{\circ} \mathrm{C}$, for 8 days, to obtain cyathostome larvae. Larvae were identified to the genus level as described by Bevilaqua et al. (1993). EPG and larvae recovered from coprocultures of animals of both treated and control groups were recorded and percentage of larval reduction was determined according to Mendoza-DeGuives et al. (1999):

reduction $(\%)$

mean $\mathrm{L}_{3}$ recovered from control group

$$
=\frac{- \text { mean } L_{3} \text { recovered from treated group }}{\text { mean } L_{3} \text { recovered from control group }} \times 100
$$

Every 15 days, two herbage samples were collected from both the treated and control groups, from each paddock, in a zigzag pattern from several and alternated points, 0-20 and $20-40 \mathrm{~cm}$ away from fecal pats, in each paddock of the different groups, according to Amarante et al. (1996). Herbage samples were always collected in the morning at $8 \mathrm{a} . \mathrm{m}$. Then, a $500 \mathrm{~g}$ herbage sample was weighed, and parasitic nematode larvae were recovered following the procedure of Lima (1989). The samples were incubated in a drying oven at $100{ }^{\circ} \mathrm{C}$, for 3 days, to determine dry matter. Data were transformed into larvae per kg of dry matter.

Climate data referring to averages of maximum, average and minimum monthly temperatures, air relative humidity and monthly rainfall were daily recorded in a meteorological station in the area.

The egg count curves (EPG) originated from the coprocultures, number of infective larvae recovered from paddocks $\left(\mathrm{L}_{3}\right)$, correlation between EPG and recovered $\mathrm{L}_{3}$ 


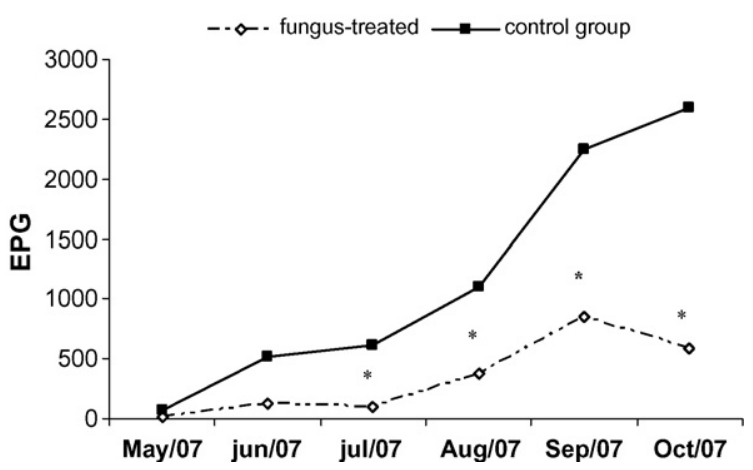

Fig. 1. Monthly means of eggs per gram of feces (EPG) of fungus-treated and control animals collected from May to October 2007, Viçosa, MG, Brazil. Significant difference $(p<0.01)$ between the treated group and the control denoted by asterisk-Tukey test.

and animal weight were compared over the experimental period. Data were transformed into $\log (x+1)$ and then examined by analyses of variance (ANOVA) and Tukey's multiple comparison test with $1 \%$ probability. The analyses were performed using the BioEstat 3.0 Software (Ayres et al., 2003).

\section{Results}

Fig. 1 shows the monthly mean EPG counts. EPG of animals treated with $D$. flagrans was significantly lower $(p<0.01)$ than the control group, especially in the last 4 months of the experiment, in which the EPG monthly mean of the treated group was $46.2 \%$ lower than the control group. July, August, September and October showed smaller percentages of EPG reduction for fungus-treated animals than the control group; 35.4\%, 73.2\%, 64.3\% and $30.5 \%$, respectively. Additionally, fungus-treated animals had EPG values lower than the control group throughout the experiment. Fig. 2 shows the coproculture data. There was significant difference $(p<0.01)$ between the results of fungus-treated animals and the control group in the last 4 months of the experiment (July, August, September and October) with larval reduction of $57.2 \%, 59.4 \%, 68.5 \%$ and $51 \%$ respectively.

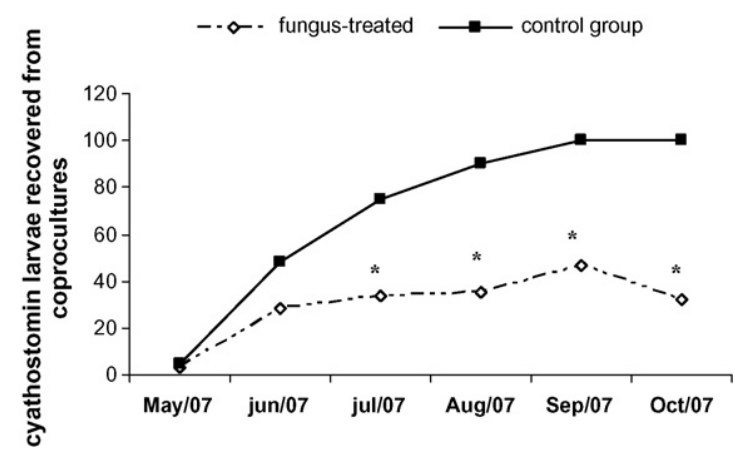

Fig. 2. Mean monthly number of cyathostomin larvae recovered from coproculture of fungus-treated horses and control group collected from May to October 2007, Viçosa, MG, Brazil. Significant difference $(p<0.01)$ between the treated group and the control denoted by asterisk-Tukey test.

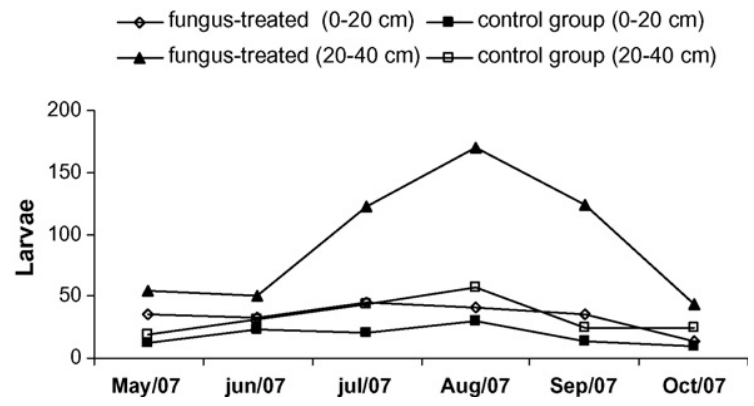

Fig. 3. Monthly counts of number of infective nematode larvae per kilogram of dry matter recovered from pastures of fungus-treated horses and control collected in sampling distances up to 20 and $20-40 \mathrm{~cm}$ from fecal pats, from May to October 2007, Viçosa, MG, Brazil.

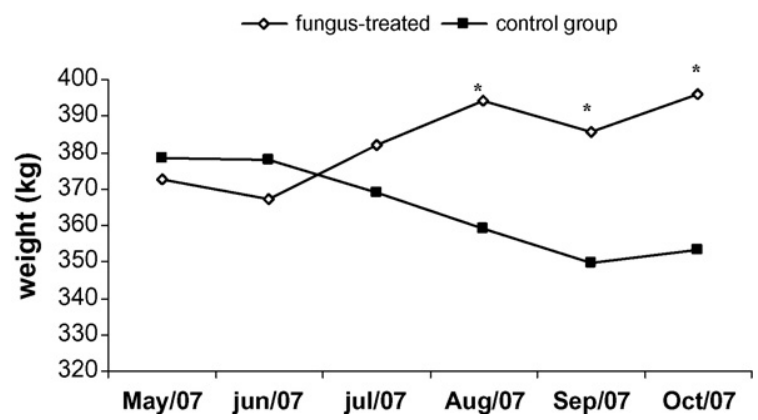

Fig. 4. Monthly means of weight ( $\mathrm{kg}$ ) of fungus-treated horses and control from May to October 2007, Viçosa, MG, Brazil. Significant difference $(p<0.01)$ between the treated group and the control denoted by asterisk-Tukey test.

Fig. 3 shows the number of larvae recovered from paddocks in the distances $(0-20 \mathrm{~cm})$ and $(20-40 \mathrm{~cm})$ away from the fecal pats. There was a significant difference $(p<0.01)$ of $78.5 \%$ for the $0-20 \mathrm{~cm}$ samples between the treated group and the control, from May to October. Significant difference $(p<0.01)$ of $82.5 \%$ was also found for the distance $20-40 \mathrm{~cm}$ from the fecal pats between the treated group and the control in the same period.

Fig. 4 shows the weights of animals from both groups. There was no significant difference $(p>0.01)$ for animal weight during the first 3 months of the year (May, June and July) between the two groups. However, in the last 3 months of the experiment (August, September and October), significant differences $(p<0.01)$ of $9.74 \%$, $10.26 \%$ and $12.21 \%$, respectively, were found for the weight between treated and non-treated animals.

\section{Discussion}

Amarante et al. (1996) states that the parameter EPG count allows evaluation of infection levels in animals and levels of pasture infestation by gastrointestinal nematode parasites. A number of studies on $D$. flagrans using horses and ruminants recorded average monthly EPG counts lower for treated animals than for non-treated groups (Baudena et al., 2000b; Knox and Faedo, 2001; Fontenot et al., 2003; Araújo et al., 2006; Paraud et al., 2007). The efficacy of $D$. flagrans on gastrointestinal parasites of 
ruminants was also demonstrated in the work of Dimander et al. (2003). These findings are in agreement with results obtained in the present work, confirming that the fungus acts on the infective forms in the fecal environment, with consequently decrease in EPG. There is nevertheless a lack of studies involving nematophagous fungi and equine cyathostomin (Bird and Herd, 1985; Baudena et al., 2000b).

Results seen in Fig. 2 suggest that there was a direct action of $D$. flagrans on infective cyathostomin larvae present in the pasture and a consequent lower parasitic infection of fungus-treated animals (Baudena et al., 2000a; Waghorn et al., 2003; Araújo et al., 2006). Only the occurrence of small strongyles (Cyathostominae) was observed after the coprocultures, according to the parameters described by Bevilaqua et al. (1993). Silva et al. (1993) reported that the subfamily Cyathostominae is highly prevalent in a large part of the Brazilian territory, and Carvalho et al. (1998) identified 19 species of small strongyles in necropsied horses in the state of Minas Gerais. The importance of these parasites for horses is directly related with larval cyathostomosis, a potentially fatal syndrome in most cases, and the high resistance of most gastrointestinal nematode parasites to routine antihelminthics (Reinemeyer, 1986; Reinemeyer and Herd, 1986).

The number of larvae recovered in the distances 0-20 and $20-40 \mathrm{~cm}$ from fecal pats (Fig. 3) is likely to be directly related with the use of nematophagous fungi that act directly on the $\mathrm{L}_{3}$ present in pastures, confirming that $D$. flagrans was responsible for the satisfactory reduction of environmental contamination (Araújo et al., 2004).

In a work carried out to evaluate the survival and migration of cyathostomin in Tifton 85 grass (Cynodon spp.) at three collection times (8:00 a.m., 1:00 p.m. and 5:00 p.m.), Bezerra et al. (2007) recorded the largest number of recovered cyathostomin at 8:00 a.m., however no statistical difference was found $(p<0.01)$ among the three times. Langrová et al. (2003), in a similar study in the Czech Republic, reported difference among collection times, with a higher cyathostome recovery at 8:00, 7:00 and 6:00 a.m. respectively. Hasslinger and Bittner (1984) discussed that temperature and moisture in the mornings favor the large number of $\mathrm{L}_{3}$ recovered from pastures. In the present work, the largest number of infective larvae was recovered within the distance $0-20 \mathrm{~cm}$ away from the fecal pats. This result agrees with findings reported by Quinelato et al. (2008) and Dias et al. (2007b) who recorded larger numbers of larvae recovered within 0$20 \mathrm{~cm}$ from fecal pats, confirming that the few larvae that leave the feces migrate to the herbage beyond $0-20 \mathrm{~cm}$. Stromberg (1997) points out that temperature and moisture are essential for the development of infective larvae. Only cyathostomin larvae were found in the herbage over the experimental period (May-October). Climatic conditions, such as temperature, relative humidity and rainfall favored the development of free-living stages and migration to the herbage (Figs. 5 and 6). The lowest rainfall rates occurred in July and August (12.64 and $16.96 \mathrm{~mm}^{3}$ respectively), however, the larval count was high in this period due to accumulated larval loads. June and September had the highest rainfall rates $(25.25$ and

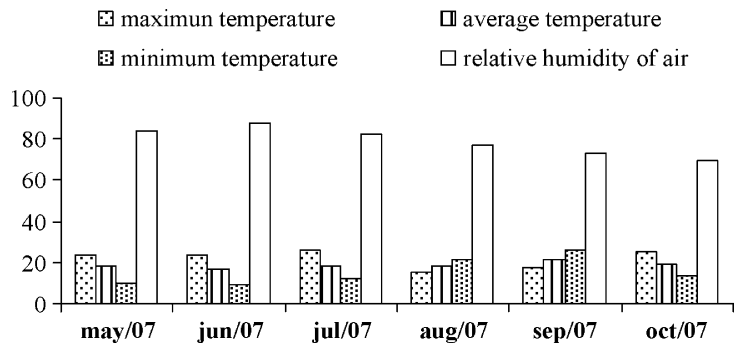

Fig. 5. Averages of maximum, average and minimum monthly temperatures $\left({ }^{\circ} \mathrm{C}\right)$ and air relative humidity (\%) recorded from May to October 2007, Viçosa, MG, Brazil.

$35.31 \mathrm{~mm}^{3}$ respectively), with the smallest larval number recorded, possibly because the $\mathrm{L}_{3}$ were washed off by rain (Figs. 3 and 6). Quinelato et al. (2008), working in the tropical southeastern Brazil, reported higher recovery of cyathostomin larvae from herbage and later from feces in the dry period, observing that the environmental conditions were favorable for recovering these larvae. The authors also argued that horses might be infected throughout the year in tropical climates, since $\mathrm{L}_{3}$ are always present in the pastures and that the grass type can affect larval recovery. Langrová et al. (2003), in central Europe, suggests that $\mathrm{L}_{3}$ respond to rain through dispersion within the vegetation, occurring a moderate correlation between moisture and $\mathrm{L}_{3}$ number in the pasture.

Courtney (1999) observed that during the dry period, the $\mathrm{L}_{3}$ development is slower, but they survive longer. Still, Fernández et al. (1997) and Baudena et al. (2000a) suggest that the survival of these parasites in the environment is strongly related with temperature and that few larvae would be found in feces in the summer. Baudena et al. (2000a) recorded field data in southern Louisiana, a region with subtropical climate in The United States, appearing that there is a larger number of infective larvae in the pasture in months with mild temperatures. This agrees with the results found in this work, in which the largest number of larvae recovered in pastures was found during months of mild temperatures (Fig. 3). Peña et al. (2002) and Chandrawathani et al. (2004) reported reduction of more than $90 \%$ of infective larvae present in fecal pats of ruminants using $D$. flagrans.

Fontenot et al. (2003) also discussed that besides $D$. flagrans decreasing infectious forms of gastrointestinal nematode parasites in pastures, it would avoid contamination of new animals entering these sites.

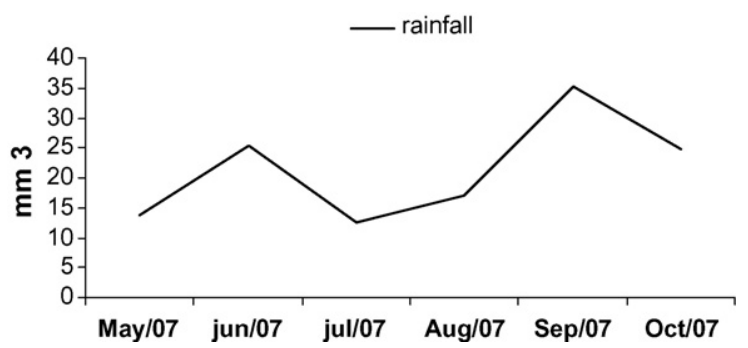

Fig. 6. Monthly rainfall $\left(\mathrm{mm}^{3}\right)$ recorded from May to October 2007, Viçosa, MG, Brazil. 
The correlation coefficient between EPG and infective larvae recovered from paddocks of group 1 within $0-20 \mathrm{~cm}$ from fecal pats was 0.0662 ; and for the distance $20-40 \mathrm{~cm}$ was 0.0416 . For group 2, the correlation coefficient between EPG and infective larvae recovered within 0$20 \mathrm{~cm}$ from the fecal pats was -0.0394 and within 20$40 \mathrm{~cm}$ was 0.0401 . These results showed weak, nonsignificant correlations, close to zero, nevertheless, as Dias et al. (2007b) pointed out, there might be dependence between EPG and infective larvae recovered from pastures even if the correlations are null. Besides, the availability of larvae on pasture may be determined by contamination from animals, as well as environmental factors, parasite and host (Lima et al., 1997).

D. flagrans is considered the most promising species in for biological control of gastrointestinal nematode parasites of livestock (Faedo et al., 2002). It has been used successfully in several laboratory and field studies (Araújo et al., 2006). Baudena et al. (2000b) proved the effectiveness of $D$. flagrans to reduce recovery of cyathostomin larvae from pastures. The authors reported reduction in the percentage of recovered larvae in animals that received doses of $2 \times 10^{6}$ spores $/ \mathrm{kg}$ of live weight during 4 days compared with the control.

In a work testing two fungal isolates of the genus Monacrosporium, Assis and Araújo (2003) found fungal mycelia in horse feces up to $96 \mathrm{~h}$ after passing through the gastrointestinal tract of horses. In this work, $D$. flagrans was offered twice a week, for an efficient weekly coverage.

In Malaysia, Chandrawathani et al. (2003) confirmed the effectiveness of daily administration of $D$. flagrans to sheep. Terrill et al. (2004) also reported reduction of larvae in feces of goats infected with predominantly Haemonchus contortus. They also found that the daily administration of fungi ( $D$. flagrans) was more effective than every 2 or 3 days. The frequency of treatments in this work promoted reduction of pasture contamination, mainly the weekly treatment.

The difference $(p<0.01)$ found in weight gain of treated animals compared to the control group may have been caused by a lower parasite load in animals that received pellets containing $D$. flagrans mycelia, which may have contributed to a better food conversion of treated animals. These results are similar to those found by Dias et al. (2007a) on weight gain of cattle treated with pellets containing $D$. flagrans mycelia.

The findings reported in this study suggest that the nematophagous fungus $D$. flagrans could be used in an integrated program to control horse cyathostomin in southeastern Brazil. It demonstrated the usefulness of a previous anthelmintic treatment to reduce the parasite load in animals and consequently the EPG, and starting from that to supply animal feed combined with the fungus to control the larval forms present in the environment and thus prevent reinfection.

\section{Conclusion}

Treatment of horses with pellets containing mycelial mass of the nematophagous fungus $D$. flagrans can be effective to control cyathostomin in tropical southeastern Brazil.

\section{Acknowledgements}

The authors would like to thank Fapemig and CNPq for the financial support and grant concession.

\section{References}

Amarante, A.F.T., Padovani, C.R., Barbosa, M.A., 1996. Contaminação de larvas de nematóides gastrintestinais parasitos de bovinos e ovinos em Botucatu-SP. Rev. Bras. Parasitol. Vet. 5, 65-73.

Araújo, J.V., Freitas, B.W., Vieira, T.C., Campos, A.K., 2006. Avaliação do fungo predador de nematóides Duddingtonia flagrans sobre larvas infectantes de Haemonchus contortus e Strongyloides papillosus de caprinos. Rev. Bras. Parasitol. Vet. 15, 76-79.

Araújo, J.V., Mota, M.A., Campos, A.K., 2004. Controle de helmintos de animais por fungos nematófagos. Rev. Bras. Parasitol. Vet. 13, 165-169.

Araújo, J.V., Sampaio, W.M., 2000. Effects of temperature, mineral salt and passage through gastrointestinal tract of calves on alginate formulation of Arthrobotrys robusta. Rev. Bras. Parasitol. Vet. 9, 55-59.

Araújo, J.V., Sampaio, W.M., Vasconcelos, R.S., Campos, A.K., 2000. Effects of different temperatures and mineral salt on pellets of Monacrosporium thaumasium-a nematode-trapping fungus. Vet. Arhiv. 80, 181-190.

Assis, R.C.L., Araújo, J.V., 2003. Avaliação da viabilidade de duas espécies de fungos predadores do gênero Monacrosporium sobre ciatostomíneos após a passagem pelo trato gastrintestinal de eqüinos em formulação de alginato de sódio. Rev. Bras. Parasitol. Vet. 12, 109-113.

Ayres, M., Ayres, J.R.M., Ayres, D.L., Santos, A.S., 2003. Aplicações estatísticas nas áreas de ciências biológicas. Sociedade civil mamirauá: Brasília CNPq, Belém, p. 290.

Barbosa, O.F., Rocha, U.F., Silva, G.S., Soares, V.E., Veronez, V.A., Oliveira, G.P., Landim, V.J.C., Costa, A.J., 2001. A survey on Cyathostominae nematodes (Strongylidea, Strongylidae) in pasture bred horses from São Paulo State, Brazil. Ciências A 22, 21-26.

Baudena, M.A., Chapman, M.R., Larsen, M., Klei, R.R., 2000a. Efficacy of the nematophagous fungus Duddingtonia flagrans in reducing equine cyathostome larvae on pasture in south Lousiana. Vet. Parasitol. 89, 219-230.

Baudena, M.A., Chapman, M.R., French, D.D., Klei, R.R., 2000b. Seasonal development and survival of equine cyathostome larvae on pasture in south Louisiana. Vet. Parasitol. 88, 51-60.

Bevilaqua, C.M.L., Rodrigues, M.L., Cocordet, D., 1993. Identification of infective larvae of some common Eqüinos strongylids of horses. Rev. Méd. Vét. 144, 989-995.

Bezerra, S.Q., Couto, M.C.M., Souza, T.M., Bevilaqua, C.M.L., Anjos, D.H.S., Sampaio, I.B.M., Rodrigues, M.L.A., 2007. Cyathostominae (strongylidae-cyathostominae) horse parasites: experimental ecology of free living stages on pasture tifton 85 (cynodon spp. cv. tifton 85) in baixada fluminense, RJ, Brazil. Parasitol. Latinoam. 62, 27-34.

Bird, J., Herd, R.P., 1985. In vitro assessment of two species of nematophagous fungi (Arthrobotrys oligospora and Arthrobotrys flagrans) to control the development of infective cyathostome larvae from naturally infected horses. Vet. Parasitol. 56, 181-187.

Chandrawathani, P., Jamnah, O., Adnan, M., Waller, P.J., Larsen, M., Gillespie, A.T., 2004. Fields studies on the biological control the nematodes parasites of sheep in the topics, using microfungus Duddingtonia flagrans. Vet. Parasitol. 120, 177-187.

Chandrawathani, P., Jaminah, O., Waller, P.J., Larsen, M., Gillespie, A.T., Zahari, W.M., 2003. Biological control of nematode parasites of small ruminants in Malaysia using the nematophagous fungus Duddingtonia flagrans. Vet. Parasitol. 117, 173-183.

Carvalho, R.O., Silva, A.V.M., Santos, H.A., Costa, H.M.A., 1998. Nematodes Cyathostominae parasites of Equus caballus in the state of Minas Gerais, Brasil. Rev. Bras. Parasitol. Vet. 7, 165-168.

Courtney, C.H., 1999. Seasonal transmission of equine cyathostomin in warm climates. Vet. Parasitol. 85, 173-180.

Dias, A.S., Araújo, J.V., Campos, A.K., Braga, F.R., Fonseca, T.A., 2007a. Application of a formulation of the nematophagous fungus Duddingtonia flagrans in the control of cattle gastrointestinal nematodioses. World J. Microbiol. Biotechnol. 28, 10.1007.

Dias, A.S., Araújo, J.V., Campos, A.K., Braga, F.R., Fonseca, T.A., 2007b. Relação entre larvas recuperadas da pastagem e contagem de ovos por grama de fezes (OPG) de nematóides gastrintestinais de bovinos na 
microrregião de Viçosa, Minas Gerais. Rev. Bras. Parasitol. Vet 16, 33-36.

Dimander, S.O., Höglund, J., Uggla, A., Spörndly, E., Waller, P.J., 2003. Evaluation of gastro-intestinal nematode parasite control strategies for first-season grazing cattle in Sweden. Vet. Parasitol. 111, 192-209.

Duddington, C.L., 1955. Notes on the technique of handling predaceous fungi. Trans. Br. Mycol. Soc. 38, 97-103.

Faedo, M., Larsen, M., Dimander, S.O., Yeates, G.W., Höglund, J., Waller, P.J., 2002. Growth of the Fungus Duddingtonia flagrans in soil surrounding feces deposited by cattle or sheep fed the fungus to control nematode parasites. Biol. Control. 23, 64-70.

Fernández, A.S., Larsen, M., Nansen, P., Gronvold, J., Henriksen, S.A., Wolstrup, J., 1997. Effect of the nematode-trapping fungus Duddingtonia flagrans on the free-living stages of horse parasitic nematodes: a plot study. Vet. Parasitol. 73, 257-266.

Fontenot, M.E., Miller, J.E., Peña, M.T., Larsen, M., Gillespie, A., 2003. Efficiency of feeding Duddingtonia flagrans chlamydospores to grazing ewes on reducing availability of parasitic nematode larvae on pasture. Vet. Parasitol. 118, 203-213.

Gordon, H.M., Whitlock, H.V., 1939. A new technique for counting nematode eggs in sheep faeces. J. Coun. Sci. Ind. Res. 12, 50-52.

Hasslinger, M.A., Bittner, G., 1984. Zur Saisondynamik gives larven von pferdestrongyliden und deren beziehung zoom infektiosrisko auf weid. Zentralbblatt fürVeterinärmedizin 31, 25-31.

Kaplan, R.M., 2002. Antihelmintic resistance in nematodes of horses. Vet. Res. Commun. 33, 491-507.

Klei, T.K., Chapman, M.R., 1999. Immunity in equine cyathostome infections. Vet. Parasitol. 85, 123-136.

Knox, M.R., Faedo, M., 2001. Biological control of field infections of nematode parasites of young sheep with Duddingtonia flagrans and effects of spore in take on efficacy. Vet. Parasitol. 101, 155-160.

Lackey, B.A., Muldoon, A.E., Jaffe, B.A., 1993. Alginate pellet formulation of Hirsutella rossiliensis for biological control of plant-parasitic nematodes. Biol. Control. 3, 155-160.

Langrová, I., Jankovská, I., Borovský, M., Fiala, T., 2003. Effect of climatic influences on the migrations of infective larvae of Cyathostominae. Vet. Méd. 48, 18-24.

Lima, W., 1989. Dinâmica das populações de nematóides parasitos gastrintestinais em bovinos de corte, alguns aspectos da relação parasitohospedeiro e do comportamento dos estádios de vida livre na região do Vale do Rio Doce, MG, Brasil. Tese (Doutorado) - Instituto de Ciências Biológicas da Universidade Federal de Minas-Gerais, Belo Horizonte, 78 p.

Lima, W.S., Fakuri, E., Guimarães, M.P., 1997. Dinâmica de helmintoses de bovinos de leite na região metalúrgica de Minas Gerais. Rev. Bras. Parasitol. Vet. 6, 97-103.
Matthews, J.B., Hodgkinson, J.E., Dowdall, S.M.J., Proudman, C.J., 2004. Recent developments in research into the Cyathostominae and Anoplocephala perfoliata. Vet. Res. 35, 371-381.

Mendoza-De-Guives, P., Davies, K.G., Clarck, S.J., Behnke, J.M., 1999. Predatory behaviour of trapping fungi against srf mutants od Caenorhabditis elegans and different plant and animal parasitic nematodes. Parasitology 119, 95-104.

Mota, M.A., Campos, A.K., Araújo, J.V., 2003. Controle biológico de helmintos parasitos de animais: estágio atual e perspectivas futuras. Pesq. Vet. Bras. 23, 93-100.

Paraud, C., Pors, I., Chartier, C., 2007. Efficiency of feeding Duddingtonia flagrans chlamydospores to control nematode parasites of first-season grazing goats in France. Vet. Res. Commun. 31, 305-315.

Peña, M.T., Miller, J.E., Fontenot, M.E., Gillespie, A., Larsen, M., 2002. Evaluation of Duddingtonia flagrans in reducing infective larvae of Haemonchus contortus in feces of sheep. Vet. Parasitol. 103, 259-265.

Quinelato, S., Couto, M.C.M., Ribeiro, B.C., Santos, C.N., Souza, L.S., Anjos, D.H.S., Sampaio, I.B.M., Rodirgues, L.M.A., 2008. The ecology cyathostomin infective larvae (Nematoda-Cyathostominae) in tropical southeast Brazil. Vet. Parasitol. 153, 100-107.

Reinemeyer, C.R., 1986. Small strongyles-recent advances. Vet. Clin. North Am.-Equine Pract. 2, 281-312.

Reinemeyer, C.R., Herd, R.P., 1986. Anatomic distribution of cyathostome larvae in the horse. Am. J. Vet. Res. 47, 510-513.

Santos, M., Ferraz, S., Muchovej, J., 1991. Detection and ecology of nematophagous fungi from Brazil soils. Nematol. Bras. 15, 121-134.

Silva, A.V.M., Costa, H.M.A., Santos, H.A., Carvalho, R.O., 1993. Cyathostominae (Nematoda) parasites of Equus caballus in some Brazilian states. Vet. Parasitol. 86, 15-21.

Stromberg, B.E., 1997. Environmental factors influencing transmission. Vet. Parasitol. 72, 247-264.

Terrill, T.H., Larsen, M., Samples, O., Husted, S., Miller, J.E., Kaplan, R.M., Gelaye, S., 2004. Capability of the nematode-trapping fungus Duddingtonia flagrans to reduce infective larvae of gastrointestinal nematodes in goat feces in the southeastern United States: dose titration and dose time interval studies. Vet. Parasitol. 120, 285-296.

Waghorn, T.S., Leathwick, D.M., Chen, L.-Y., Skipp, R.A., 2003. Efficacy of the nematode-trapping fungus Duddingtonia flagrans against three species of gastro-intestinal nematodes in laboratory faecal cultures from sheep and goats. Vet. Parasitol. 118, 227-234.

Walker, H.L., Connick, W.J., 1983. Sodium alginate for production and formulation of mycoherbicides. Weed. Sci. 31, 333-338.

Waller, P.J., Larsen, M., Faedo, M., Henessy, D.R., 1994. The potential of nematophagous fungi to control the free-living stages of nematodes parasites of sheep: in vitro and in vivo studies. Vet. Parasitol. 51, 289-299. 